\title{
Kinetic properties of growth of intestinal sulphate-reducing bacteria isolated from healthy mice and mice with ulcerative colitis
}

\author{
Ivan Kushkevych ${ }^{1,2}$, Monika Vítězová ${ }^{1}$, Pavla Fedrová1, Zora Vochyanová ${ }^{3}$, \\ Lenka Paráková ${ }^{2}$ Jan Hošek ${ }^{3}$ \\ ${ }^{1}$ Masaryk University, Faculty of Science, Department of Experimental Biology, \\ Section of Microbiology, Brno, Czech Republic \\ ${ }^{2}$ University of Veterinary and Pharmaceutical Sciences Brno, Faculty of Pharmacy, \\ Department of Human Pharmacology and Toxicology, Brno, Czech Republic \\ ${ }^{3}$ University of Veterinary and Pharmaceutical Sciences Brno, Faculty of Pharmacy, \\ Department of Molecular Biology and Pharmaceutical Biotechnology, Brno, Czech Republic
}

Received January 13, 2017

Accepted December 19, 2017

\begin{abstract}
Inflammatory bowel disease including ulcerative colitis are complex multifactorial diseases of unknown aetiology. Sulphate-reducing bacteria are often associated with the occurrence of the disease. The physiological properties of intestinal sulphate-reducing bacteria including kinetic characteristic of their growth have never been reported. The aim of this research was to evaluate the presence of sulphate-reducing bacteria isolated from the intestines of mice, study their growth, calculate and compare the kinetic growth properties on the model of dextran sulphate sodium induced ulcerative colitis in the mice. The number of viable intestinal sulphate-reducing bacteria from the bowel lumen of mice with ulcerative colitis was higher $(P>0.05)$ by $22 \%$ at $12 \mathrm{~h}$ of cultivation compared with cultures of sulphate-reducing bacteria from the bowel lumen of healthy mice. The sulphate-reducing bacteria from mice with colitis also had a slightly higher generation time $(14.29 \mathrm{~h})$ and exponential growth phase $(22.24 \mathrm{~h})$ compared with cultures from healthy mice. The time of lag-phase was $2 \times$ shorter $(P>0.01)$ in the cultures of sulphate-reducing bacteria from mice with ulcerative colitis. The described research is new and important for the prediction of the sulphate-reducing bacteria number in the gut and their rate of dissimilatory sulphate reduction. The kinetic characteristic of their growth is important for further clarification of the mechanisms of sulphate reduction and accumulation of hydrogen sulphide, which is toxic for epithelial cells of the intestine and can cause bowel diseases both in humans and animals, in particular ulcerative colitis.
\end{abstract}

Intestinal microbiota, growth rate, hydrogen sulphide, bowel diseases

Sulphate-reducing bacteria (SRB) are widespread in anaerobic areas of soils, wetlands, fresh and marine waters and available in the microbiota of the large intestine of humans and animals (Barton and Hamilton 2010). These microorganisms metabolize sulphate as an electron acceptor to hydrogen sulphide. The sulphate dissimilation process is called the "dissimilatory sulphate reduction" or "sulphate respiration" (Kushkevych 2016a,b). For this process, SRB needs exogenous electron donors, including organic compounds or molecular hydrogen. Dependent on SRB genera, organic compounds are oxidized incompletely to acetate (acetogenic SRB) or completely to carbon (IV) oxide (Barton and Hamilton 2010).

The intensity of sulphate reduction in SRB and, accordingly, the accumulation of hydrogen sulphide in high or toxic concentrations in the intestines can lead to the development of various diseases (Kushkevych 2014a). Hydrogen sulphide is the final product in the sulphate reduction process of SRB metabolism. At high concentrations, this final metabolite

Address for correspondence:

Ivan Kushkevych, M.Sc., Ph.D., Dr.Sc., Assoc. Prof.

Section of Microbiology

Department of Experimental Biology, Masaryk University

Kamenice 753/5, 62500 Brno, Czech Republic
Phone: +420549 495315
Fax: +420 541211214
E-mail: kushkevych@mail.muni.cz
http://actavet.vfu.cz/ 
is toxic and carcinogenic for the intestinal cell and can cause inhibition of cytochrome oxidase, colonocytes oxidation of butyrate, destruction of epithelial cells, and development of ulcers and inflammation with subsequent development of ulcerative colitis (Pitcher et al. 1996; Gibson et al. 1991; Cummings et al. 2003; Kushkevych 2015c,d).

Acetogenic SRB and their final products of metabolism (including hydrogen sulphide and acetate) are often found in the faeces of people with bloody diarrhoea (Pitcher et al. 1996) and the mono and polymicrobial infections of the gastrointestinal tract (McDougall et al. 1997). It is believed that SRB can cause frequent defecation, weight loss, and increased intestinal permeability (Kushkevych 2016b). The species and quantitative composition of the SRB on the surface of the intestinal mucosa are different from those microorganisms in the lumen (Macfarlane et al. 2000, 2007; Zinkevich et al. 2000; Kushkevych 2015e). Such genera of SRB, Desulfovibrio, Desulfomicrobium, Desulfobacter, Desulfobulbus, Desulfotomaculum, Lawsonia and Bilophila, are the most isolated from the intestines of healthy and ill humans and animals (Gibson et al. 1991, 1993; Kushkevych 2016b).

The number of cases of inflammatory bowel disease (IBD) including ulcerative colitis (UC) is growing. The cause of the occurrence is still unknown (Cummings et al. 2003). This disease is mostly observed in the human population of the age group of 15-30 years; although there is clear evidence of this disease occurring in the human population of the age group of 50-70 years, which can be labelled as a potential risk group. Frequent cases of this disease are recorded in both developed and underdeveloped countries (Garud and Peppercorn 2009). Ulcerative colitis is diagnosed not only in people but also in animals; e.g., horses, cows, pigs, dogs, cats, and rodents (mice and rats). However, the functional role of SRB in the development of inflammatory bowel disease including ulcerative colitis and their participation in the mechanisms of the disease have never been studied properly. The physiological properties of intestinal SRB including the kinetic characteristic of the SRB growth (doubling time, absolute and relative (specific) growth rate, the maximum growth rate and time of lag-phase) and their comparison between healthy mice and mice with induced ulcerative colitis, have never been reported.

The aim of our research was to induce ulcerative colitis in mice using dextran sulphate sodium, accumulate the SRB cultures from the intestines of healthy mice and of mice with ulcerative colitis, isolate and identify SRB cultures to study their growth, calculate and compare the kinetic growth properties.

\section{Manipulation with animals}

\section{Materials and Methods}

Male C57Bl/6 mice (20 g $\pm 2 \mathrm{~g}$ ) were obtained from the Animal Breeding Facility of Masaryk University (Brno, Czech Republic). They were kept under standard conditions $\left(22 \pm 2{ }^{\circ} \mathrm{C}, 50 \pm 10 \%\right.$ relative humidity) and alternating $12 \mathrm{~h}$ light/dark cycles. The animals had access to a standard diet and drinking water ad libitum. Manipulations with the animals were carried out according to the bioethical rules as per the principles of the "European Convention for the Protection of Vertebrate Animals Used for Experimental and Other Scientific Purposes" adopted in Strasbourg in 1986. The study was also approved by the "Commission for the Protection of Animals against Cruelty" and the Ethics Committee of the University of Veterinary and Pharmaceutical Sciences in Brno, Czech Republic.

In total, 6 animals in two groups $(4+2$ animals in the first and second group, respectively) were randomly separated and used in this experiment. In the dextran sulphate sodium (DSS) group $(n=4)$, colitis was induced by administering 5\% (w/v) DSS (MP Biomedicals, Illkirch-Graffenstaden, France; MW 36.000-50.000 Da) in drinking water for 7 days. The mice in the intact group $(n=2)$ received drinking water only. On the last day of experiment, the animals were killed by decapitation under isoflurane anaesthesia. The isolated distal colonic segments were selected for the analysis of qualitative and quantitative composition of intestinal microflora of both groups of the animals.

\section{Accumulation of intestinal SRB}

In total, $100 \mathrm{mg}$ of faeces were taken from healthy mice and mice with UC. A $5 \mathrm{~mm}$-piece of the intestine was also taken for studying SRB which can be in biofilms from both groups of animals. All samples were suspended in tubes (volume $1.5 \mathrm{ml}$ ) with pre-heated $\left(36.6^{\circ} \mathrm{C}\right.$ ) liquid modified Postgate's medium I (Postgate 1984) of the following composition (g/l): $\mathrm{Na}_{2} \mathrm{SO}_{4}(4.0), \mathrm{KH}_{2} \mathrm{PO}_{4}(0.3), \mathrm{K}_{2} \mathrm{HPO}_{4}(0.5),\left(\mathrm{NH}_{4}\right)_{2} \mathrm{SO}_{4}(0.2), \mathrm{NH}_{4} \mathrm{Cl}$ 
(1.0), $\mathrm{CaCl}_{2} \times 6 \mathrm{H}_{2} \mathrm{O}(0.06), \mathrm{MgSO}_{4} \times 7 \mathrm{H}_{2} \mathrm{O}(1.0), \mathrm{C}_{3} \mathrm{H}_{6} \mathrm{O}_{3}(6 \mathrm{ml})$, yeast extract (1.0), $\mathrm{Na}_{3} \mathrm{C}_{6} \mathrm{H}_{5} \mathrm{O}_{7} \times 2 \mathrm{H}_{2} \mathrm{O}(0.3)$. Additional solutions $(\mathrm{g} / \mathrm{l})$ were prepared separately using deionized water: sodium pyruvate $(2 \mathrm{~g}$ in $100 \mathrm{ml}$ of $\left.\mathrm{H}_{2} \mathrm{O}, 100 \mathrm{ml}\right), \mathrm{NaHCO}_{3}\left(2 \mathrm{~g}\right.$ in $50 \mathrm{ml}$ of $\left.\mathrm{H}_{2} \mathrm{O}, 50 \mathrm{ml}\right), \mathrm{Na}_{2} \mathrm{~S}_{2} \mathrm{O}_{4}\left(30 \mathrm{mg}\right.$ in $1 \mathrm{ml}$ of $\left.\mathrm{H}_{2} \mathrm{O}, 1 \mathrm{ml}\right)$, Mohr's salt solution ((NH4) $\left.\mathrm{SO}_{4} \mathrm{Fe}\left(\mathrm{SO}_{4}\right)_{2} \times 6 \mathrm{H}_{2} \mathrm{O}\right)(10 \%) 10 \mathrm{ml}, \mathrm{Na}_{2} \mathrm{~S}^{2} \times \mathrm{H}_{2} \mathrm{O}(1 \%) 3 \mu$ l. The medium and solutions were sterilized separately. Each of these 5 solutions was added to the medium. To adjust the $\mathrm{pH}$ value on 8.5 sterile $10 \mathrm{~N}$ solution of $\mathrm{NaOH}$ was used. The redox and anaerobic conditions were controlled by resazurin sodium (Oxoid, $\mathrm{BR} 0055 \mathrm{~B}$ ) as an indicator. In addition, reduced $\mathrm{FeS}$ and $\mathrm{Na}_{2} \mathrm{~S}$ contained in the medium provided the necessary redox conditions for SRB cultures. The discoloration of resazurin sodium (redox potential of discoloration $\mathrm{Eh}=-100 \mathrm{mV}$ ) confirmed the decrease of the redox potential. The SRB suspensions were cultivated at $36.6{ }^{\circ} \mathrm{C}$ under anaerobic conditions for $48 \mathrm{~h}$. The tubes were filled with medium and closed by a rubber plug to provide anaerobic conditions. The positive cultures of SRB created a black sediment because Mohr's salt solution was added to the medium. As a result, FeS was formed by the bacterial cells that caused the black sediment.

\section{Isolation and identification of intestinal SRB pure cultures}

For isolation of the SRB pure cultures, each positive suspension with SRB was diluted to $10^{-12}$ in a series of tubes containing the liquid medium I. To obtain colonies for isolation, the same Postgate's agar (12 g/l) medium I was prepared. To prevent solidification, the medium I in Erlenmeyer flask $(500 \mathrm{ml})$ was placed in water bath tempered to $45^{\circ} \mathrm{C}$. To obtain isolated SRB colonies, $20 \mathrm{ml}$ of agar medium I $+100 \mu \mathrm{l}$ of each dilution suspension were mixed and consequently poured to Petri dishes. After cooling down, the dishes were placed into an anaerobic box with oxygen uptake generators (GENbox anaer, bioMérieux, France) for anaerobiosis. The cultivation was carried out in incubator ES 120 (Nüve, Turkey) operated at $36.6 \pm 0.5^{\circ} \mathrm{C}$. Black colonies were visible on the agar medium after $24 \mathrm{~h}$ of cultivation.

Isolated colonies were taken in the liquid medium I and grown for another $24 \mathrm{~h}$. To make sure the samples were pure culture, this process was repeated $\times 2-3$. The identification of SRB was carried out as described previously (Kushkevych 2013; Kushkevych et al. 2014b). The SRB isolates were identified as Desulfovibrio genus. Additional tests of the identification (including morphological characteristics, physiological and biochemical properties) showed that no other genera were present. The obtained SRB cultures were kept in the Laboratory of Anaerobic Microorganisms of the Section of Microbiology and Molecular Biotechnology at the Department of Experimental Biology at the Masaryk University (Brno, Czech Republic).

\section{Testing of bacterial growth by the Bioscreen method}

For the testing of bacterial growth, the suspensions of SRB and pure culture of Desulfovibrio genus isolated from 2 healthy mice ( 5 isolates from the faeces +5 isolates from the intestinal surface which were in biofilm) as well as from 4 mice with UC ( 5 isolates from the faeces +5 isolates from the intestinal surface).

Grown SRB in the liquid medium I without Mohr's salt solution were diluted in the liquid fresh medium I (transmittance was 90 at $\lambda=620 \mathrm{~nm}$ ). Consequently, $320 \mu 1$ of each suspension obtained were pipetted to the wells (total volume $350 \mu \mathrm{l}$ ) of multiwell plates. To provide anaerobic condition, sterile paraffin oil $(30 \mu 1)$ was added to each well. As a control, the medium without any sample $(320 \mu 1)+30 \mu 1$ of sterile paraffin oil was used. For statistical evaluation, each sample was pipetted into 5 wells. For the study of bacterial growth, the Bioscreen $\mathrm{C}$ (Oy Growth Curves Ab Ltd., Finland) was used. Bioscreen was set at a temperature of $36.6^{\circ} \mathrm{C}$, measuring at a 30 -min interval within the $24 \mathrm{~h}$ of measurement.

\section{Calculation of growth indices and statistical analysis}

The growth indices of SRB were characterized by the following basic constants (Widdel 2010): generation time $(G)$, absolute growth rate $(R)$, relative (specific) rate $(\mu)$, the maximum growth rate $\left(\mu_{\max }\right)$ and duration of the lag-phase $(L)$.

Generation time $(G)$ was defined as the time $(t)$ per generation of one bacterial cell $(N=$ number of SRB cells in the interval time), in practice, it is the duration of the cell cycle of one cell:

$$
G=\frac{1}{R}=\log 2 \cdot \frac{t-t_{0}}{\log N-\log N_{0}}
$$

where $t_{0}$ is initial time $\left(t_{0}=0\right)$ and $N_{0}$ is initial number of bacterial cells $\left(N_{0}=5.69 \log _{10} \mathrm{CFU} \cdot \mathrm{ml}^{-1}\right)$. The absolute growth rate (or doubling rate) was calculated by the number of divisions (generations) per unit time. The absolute growth rate $(R)$ was defined as the number of cells formed per time:

$$
R=\frac{N}{t}=\frac{1}{\log 2} \cdot \frac{\log N-\log N_{0}}{t-t_{0}}
$$

The relative (specific) growth rate $(\mu)$ was determined by the absolute growth rate related to the population size (number cells formed per time and existing number of cells, $N$ ):

$$
\mu=\frac{d N}{d t} \cdot \frac{1}{N}=\frac{\operatorname{In} N-\ln N_{0}}{t}=2.3 \cdot \frac{\log N-\log N_{0}}{t-t_{0}}
$$

Maximum growth rate was considered as the maximum value of relative (specific) growth rate. Time of lagphase was calculated by formula: $L=t_{\mathrm{k}}-t_{\mathrm{e}}$, where $t_{\mathrm{k}}$ was the duration of the experiment, and $t_{\mathrm{e}}$ was the duration of the exponential growth phase:

$$
t_{e}=\frac{1}{\log 2} \cdot \frac{\log N-\log N_{0}}{R}=\frac{1}{\log 2} \cdot G \cdot\left(\log N-\log N_{0}\right)
$$


Kinetic and statistical calculations of the results were carried out using the software MS Office and Origin computer programs. Using the experimental data, the basic statistical parameters (mean: M, standard error: $\mathrm{m}, \mathrm{M} \pm \mathrm{m}$ ) were calculated. The research results were treated by methods of variation statistics using Student's $t$-test. The significance of the calculated indicators of line was tested by Fisher's $F$-test. The accurate approximation was when $P \leq 0.05$ (Bailey 1995).

\section{Results}

The first stage of our research was to compare the kinetic properties of SRB isolated from the lumen (faeces) of both experimental groups. The number of viable intestinal SRB from the bowel lumen of mice with UC was higher $(P>0.05)$ by $22 \%$ at $12 \mathrm{~h}$ of cultivation compared to cultures of SRB from the bowel lumen of healthy mice (Fig. 1A). These data correlate with specific maximal growth rate $\left(\mu_{\mathrm{max}}\right)$ which was also higher $(P>0.05)$ by $13 \%$ in SRB from mice with UC. The specific maximal growth rate of the SRB from both groups was achieved at $12-12.5 \mathrm{~h}$ (Fig. 1B). These microorganisms also had a slightly higher generation time $(14.29 \mathrm{~h})$ and exponential growth phase $(22.24 \mathrm{~h})$ compared to the cultures from healthy mice (Table 1). It should be noted that the time of the lag-phase was $\times 2$ shorter $(P>0.01)$ in the cultures of SRB from the faeces of mice with UC. That may indicate adaptive capacities of the SRB and their participation in the development of UC. The intestinal SRB from the faeces of healthy mice and mice with UC achieved the exponential phase after an adaptation period ( 3.49 and $1.76 \mathrm{~h}$, respectively) in the lag phase. The stationary phase was achieved after 20.51 and $22.24 \mathrm{~h}$, respectively (Table 1 ).

Sulphate-reducing bacteria can be found not only in the faeces or in the intestinal lumen but they can also be in interaction with other intestinal microorganisms in the biofilms. These biofilms are often formed by the SRB with species of Clostridium, Bacteroides or Escherichia genera. However, the features of the formation of these biofilms and the interaction of SRB with other bacterial genera are still unexplored.

Table 1. Kinetic properties of SRB cultures isolated from mice.

\begin{tabular}{|c|c|c|c|c|c|c|c|}
\hline \multirow{2}{*}{\multicolumn{2}{|c|}{$\begin{array}{l}\text { Suspension } \\
\text { of SRB from }\end{array}$}} & \multirow{2}{*}{$\begin{array}{c}t_{\mathrm{e}} \\
(\mathrm{h})\end{array}$} & \multirow{2}{*}{$\begin{array}{l}\text { Lag-phase } \\
\text { (h) }\end{array}$} & \multirow{2}{*}{$\begin{array}{c}G \\
(\mathrm{~h})\end{array}$} & \multirow{2}{*}{$\begin{array}{l}\text { Absolute rate } \\
\text { (number of cells/hour) }\end{array}$} & \multicolumn{2}{|c|}{$\begin{array}{c}\text { Specific rate } \\
\text { (number of cells/hour) }\end{array}$} \\
\hline & & & & & & Average & $\mu_{\max }$ \\
\hline \multirow{2}{*}{ 造 } & healthy & 20.51 & 3.49 & 13.13 & $0.076 \pm 0.023$ & $0.052 \pm 0.016$ & $0.063 \pm 0.011$ \\
\hline & UC & 22.24 & 1.76 & 14.29 & $0.069 \pm 0.007$ & $0.048 \pm 0.005$ & $0.071 \pm 0.002$ \\
\hline \multirow{2}{*}{ 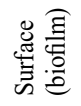 } & healthy & 19.74 & 4.26 & 12.72 & $0.079 \pm 0.009$ & $0.054 \pm 0.062$ & $0.081 \pm 0.014$ \\
\hline & $\mathrm{UC}$ & 21.21 & 2.79 & 15.48 & $0.065 \pm 0.023$ & $0.045 \pm 0.014$ & $0.060 \pm 0.005$ \\
\hline
\end{tabular}

Comment: $t_{\mathrm{e}}$ is duration of the exponential growth phase (hours), $G$ is generation time (hours), $\mu_{\max }$ is maximum growth rate, SRB: sulphate-reducing bacteria, UC: mice with ulcerative colitis

Cultures of SRB from the intestinal surface of the biofilm of healthy mice and of mice with UC were accumulated in the medium and the kinetic properties of their growth were studied (Fig. 1C). The growth of SRB cultures from the bowel surface of both groups of mice was almost the same until $4.5 \mathrm{~h}$ of cultivation. The level of growth of SRB from the biofilm of mice with UC was increased $(P>0.05)$ within the time interval of $4.5-12.5 \mathrm{~h}$ and after that they were released from the biofilm of healthy mice. The specific maximal growth rate was higher $(P>0.05)$ by $26 \%$ in SRB from healthy mice compared to mice with UC (Table 1$)$. However, maximal growth rate of SRB from the biofilm of healthy mice was achieved earlier at $1.5 \mathrm{~h}$, whereas $\mu_{\text {max }}$ of SRB from the biofilm of mice with UC was achieved later at $9.5 \mathrm{~h}$ of cultivation (Fig. 1D). These results correlated with specific means and absolute growth rates which were also higher $(P>0.05)$ by $17-18 \%$ in SRB from healthy mice. The generation time $(12.72 \mathrm{~h})$ and 
exponential growth phase $(19.74 \mathrm{~h})$ of these microorganisms were shorter $(P>0.05)$ compared to the cultures of SRB from mice with UC. It should be noted that the time of the lag-phase in SRB from surface was $\times 1.5$ shorter $(P>0.05)$ in the cultures of SRB from mice with UC. It correlated with the lag-phase in the SRB isolated from the bowel lumen of mice with UC. The stationary phase of both SRB cultures was achieved after $20 \mathrm{~h}$ of cultivation.
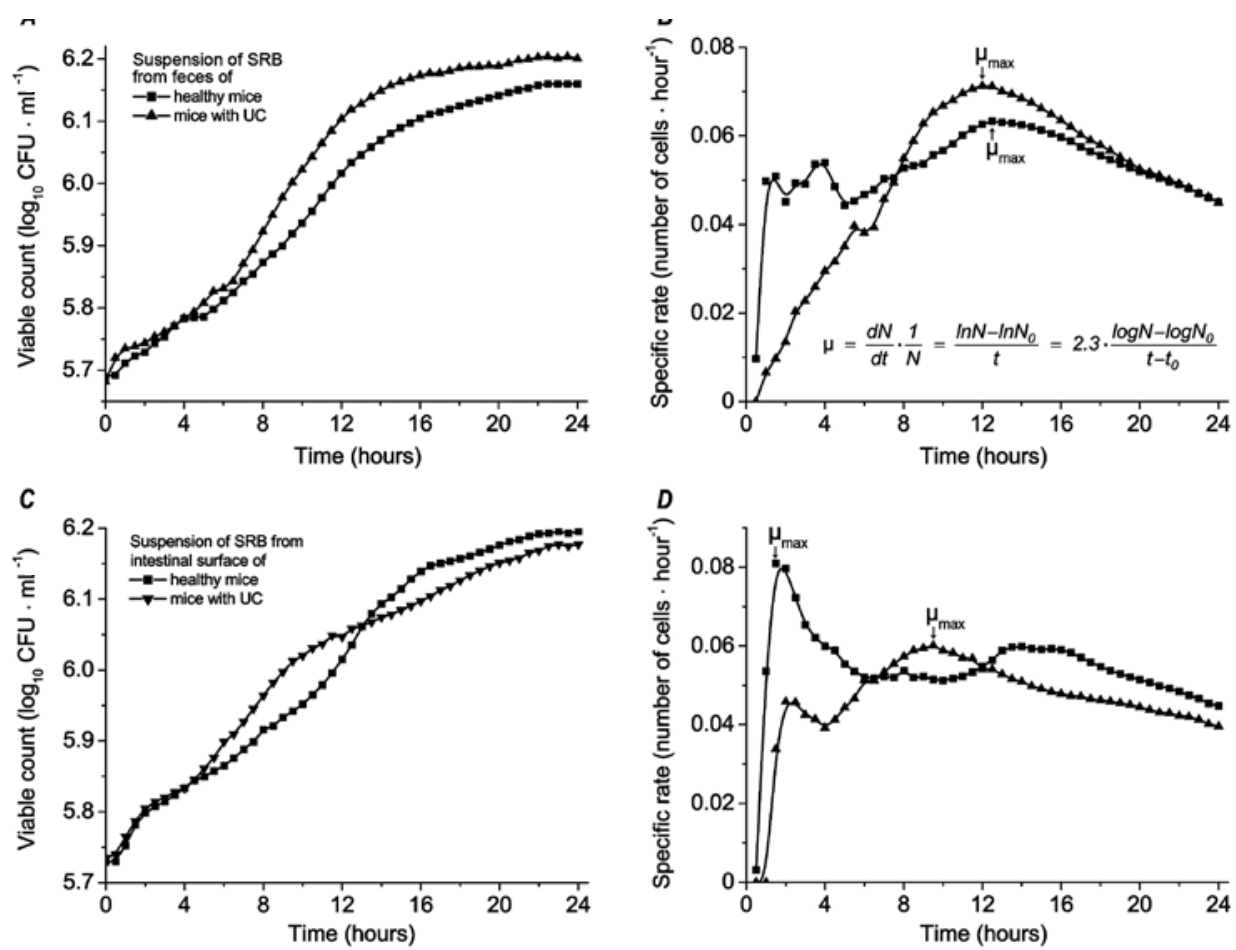

Fig. 1. Physiological indices of sulphate-reducing bacteria isolated from mice: bacterial growth $(A, C)$ and specific growth rate $(B, D)$, the arrows indicate the maximum rate of the growth and CFU is colony-forming units $(\mathrm{M} \pm \mathrm{m}, \mathrm{n}=5)$

\section{Discussion}

Inflammatory bowel disease including ulcerative colitis are complex multifactorial diseases of unknown aetiology (Cummings et al. 2003). However, the aetiological role of the sulphate-reducing bacteria Desulfovibrio genus in the development of these inflammatory diseases was demonstrated in our previous research (Kus hkevy ch 2014a). Ulcerative colitis was experimentally induced in the animals by application of sulphatereducing bacteria. The initiation of the animals' own potential intestinal microflora of sulphate-reducing bacteria was observed in those animals which obtained a dose of sulphate containing medium. The changes in the colonic microbiota were observed in the animals which received a dose of SRB suspension. The bacteria belonging to the normal colonic microbiota were associated with the aetiology of inflammatory bowel disease and ulcerative colitis. The concentration of sulphide and acetate in faeces from different sections of the large intestine was determined. The level of ulcerations in the second and third group of sick animals under the specific conditions was demonstrated (Kushkevych 2014a). 
The increasing number of viable intestinal SRB was also described previously in several researches published by Gibson et al. (1991, 1993), Kushkevych (2015a), Cummings et al. (2003), and Pitcher et al. (1996). The increasing specific maximal growth rate $\left(\mu_{\max }\right)$ of SRB from mice with UC can lead to intensive sulphate reduction (Kushkevych $2014 \mathrm{c}$ ). The increased concentration of sulphate in the intestine can lead to an increase in the specific maximal growth rate of the SRB and the production of hydrogen sulphide and acetate in high concentrations.

The reduction of sulphate ions to hydrogen sulphide occurs as a result of the formation of many intermediate compounds (Postgate 1984). The sulphate reduction enzymes are located in the cytoplasm and peripheral plasma. The initial stages of sulphate reduction include the uptake of sulphate ions in the bacterial cells. The sulphate ions can be transported into the cells simultaneously with protons and some sulphate-reducing bacteria can absorb sulphate from the flow of sodium ions (Barton and Hamilton 2007). It is known that the centre of adenosine triphosphate (ATP) hydrolysis is located on the cytoplasmic surface of the membrane. In another one of our studies, the ATPase activity in cell-free extracts of the sulphate-reducing bacteria isolated from the human large intestine was demonstrated. The maximum ATPase activity for SRB strains at $+35{ }^{\circ} \mathrm{C}$ and at $\mathrm{pH} 7.0$ was described (Kushkevych et al. 2015).

The described research is novel and important to predict the SRB number in the gut and their speed of dissimilatory sulphate reduction. The kinetic characteristic of their growth is important for further clarification of the mechanisms of sulphate reduction and accumulation of hydrogen sulphide, which is toxic for epithelial cells of the intestine and can cause bowel disease both in humans and animals, in particular ulcerative colitis. These results could be particularly useful for the study of IBD and its therapeutic strategy. These data are also indispensable for application into mechanistic details that will facilitate better preclinical drug/therapy design to target specific components involved in the disease pathogenesis.

\section{Acknowledgements}

This study was supported by the University of Veterinary and Pharmaceutical Sciences Brno (project OPVK "Pharmaco-toxicological evaluation of newly synthesized (isolated) compounds as an integration tool for preclinical disciplines at VFU Brno" CZ.1.07/2.3.00/30.0053). This project was also supported by the grant of the Ministry of Health of the Czech Republic No. 16-27522A (to Z. V. and J. H.) and by the Grant Agency of the Masaryk University (MUNI/A/0906/2016).

\section{References}

Bailey NTJ 1995: Statistical Methods in Biology. Cambridge University Press, Cambridge, 252 p.

Barton LL, Hamilton WA 2010: Sulphate-Reducing Bacteria. Environmental and Engineered Systems. Cambridge University Press, Cambridge, 553 p.

Cummings JH, Macfarlane GT, Macfarlane S 2003: Intestinal bacteria and ulcerative colitis. Curr Issues Intest Microbiol 4: 9-20

Garud S, Peppercorn MA 2009: Ulcerative colitis: Current treatment strategies and future prospects. Therap Adv Gastroenterol 2: 99-108

Gibson GR, Cummings JH, Macfarlane GT 1991: Growth and activities of sulphate-reducing bacteria in gut contents of health subjects and patients with ulcerative colitis. FEMS Microbiol Ecol 86: 103-112

Gibson GR, Macfarlane S, Macfarlane GT 1993: Metabolic interactions involving sulphate-reducing and methanogenic bacteria in the human large intestine. FEMS Microbiol Ecol 12: 117-125

Kushkevych I 2013: Identification of sulfate-reducing bacteria strains of human large intestine. Stud Biol 7: 115-132

Kushkevych I 2014a: Etiological role of sulfate-reducing bacteria in the development of inflammatory bowel diseases and ulcerative colitis. Am J Infect Dis Microbiol 2: 63-73

Kushkevych I, Bartos M, Bartosova L 2014b: Sequence analysis of the 16S rRNA gene of sulfate-reducing bacteria isolated from human intestine. Int J Curr Microbiol Appl Sci 3: 239-248

Kushkevych I 2014c: Dose-dependent effect of electron acceptor and donor on dissimilatory sulfate reduction by bacteria Desulfovibrio piger Vib-7 of human intestine. Stud Biol 8: 103-116 
Kushkevych I, Bolis M, Bartos M 2015a: Model-based characterization of the parameters of dissimilatory sulfate reduction under the effect of different initial density of Desulfovibrio piger Vib-7 bacterial cells. The Open Microbiol J 9: 55-69

Kushkevych I, Fafula R, Parák T, Bartoš M 2015b: Activity of $\mathrm{Na}^{+} / \mathrm{K}^{+}$-activated $\mathrm{Mg}^{2+}$-dependent ATP-hydrolase in the cell-free extracts of the sulfate-reducing bacteria Desulfovibrio piger Vib-7 and Desulfomicrobium sp. Rod-9. Acta Vet Brno 84: 3-12

Kushkevych I, Kollar P, Suchy P. et al. 2015c: Activity of selected salicylamides against intestinal sulfatereducing bacteria. Neuroendocrinol Lett 36:106-113

Kushkevych I 2015d: Kinetic Properties of Pyruvate Ferredoxin Oxidoreductase of Intestinal Sulfate-Reducing Bacteria Desulfovibrio piger Vib-7 and Desulfomicrobium sp. Rod-9. Polish J Microbiol 64:107-114

Kushkevych I 2015e: Activity and kinetic properties of phosphotransacetylase from intestinal sulfate-reducing bacteria. Acta Bioch Pol 62:1037-108

Kushkevych I, Kollar P, Ferreira A, Palma D, Duarte A, Lopes M, Bartos M, Pauk K, Imramovsky A, Jampilek J 2016a: Antimicrobial effect of salicylamide derivatives against intestinal sulfate-reducing bacteria. J Appl Biomed 14:125-130

Kushkevych IV 2016b: Dissimilatory sulfate reduction in the intestinal sulfate-reducing bacteria. Stud Biol 10: $197-228$

Macfarlane S, Hopkins MJ, Macfarlane GT 2000: Bacterial growth and metabolism on surfaces in the largeintestine. Microb Ecol Health Dis 2: 64-72

Macfarlane S, Dillon JF 2007: Microbial biofilms in the human gastrointestinal tract. J Appl Microbiol 102:11871196

McDougall R, Robson J, Paterson D, Tee W. 1997: Bacteremia caused by a recently described novel Desulfovibrio species. J Clin Microbiol 35: 1805-1808

Pitcher MC, Cummings JH 1996: Hydrogen sulphide: a bacterial toxin in ulcerative colitis? Gut 39: 1-4

Postgate JR 1984: The sulfate-reducing bacteria. Cambridge University Press, Cambridge, $199 \mathrm{p}$.

Widdel F 2010: Theory and Measurement of Bacterial Growth. Grundpraktikum Mikrobiologie, Universität Bremen 4: 1-11

Zinkevich V, Beech IB 2000: Screening of sulfate-reducing bacteria in colonoscopy samples from healthy and colitic human gut mucosa. FEMS Microbiol Ecol 34: 147-155 